\title{
Vojislav Ćurčić*
}

\section{PSIHOLOŠKI ODNOS PREMA TELU I GOJ AZNOST ADOLESCENATA}

\begin{abstract}
Sažetak: Početak gojaznosti u adolescenciji nije tako čest i ona je uglavnom nastavak gojaznosti u detinjstvu. Osim medicinskih, kulturoloških i porodičnih razloga, za nastanak gojaznosti u adolescenciji značajnu ulogu imaju i psihološki faktori. Psihološki faktori (stresni događaji, mentalni poremećaji, psihofarmaci) mogu biti isti kao i u drugim životnim dobima, ali se u adolescenciji doživljavaju specifično jer se umeću u specifičnosti adolescentnog procesa. Zato je potrebno problem gojaznosti posmatrati u kontekstu preobražaja koji karakterišu adolescenciju jer se samo tako mogu razumeti i samo tako može adekvatno pomoći gojaznim adolescentima.
\end{abstract}

Ključne reči: adolescencija, gojaznost, psihološki faktori

Резюме: Проблема ожирения у подростков является не такой частой и, как правило, является продолжением ожирения в детском возрасте. Кроме медицинских и семейных причин, за возникновение ожирения в подростковом возрасте, значительная роль отводится психологическим факторам. Психологические факторы (стрессовые события, ментальные нарушения, использование психофармакологических препаратов) могут быть такие же, как и в других периодах жизни, но в подростковом возрасте ощущаются особенно остро, с учетом специфики подросткого процесса. Следовательно, на проблемму ожирения необходимо смотреть в контексте измений, характерных для подросткого периода, посколько только так можно понять и адекватно помочь подросткам с ожирением.

Ключевые слова: подростковый период, ожирение, психологические факторы

Vojislav Ćurčić, prim. dr sc. med, Bolnica za psihijatriju, KBC „Dr Dragiša Mišović-Dedinje“, Beograd, Milana Tepića 1, e-mail: vcurcic@ikomline.net 


\begin{abstract}
Summary: The beginning of obesity in adolescence is not so frequent and it is mostly continuation of childhood obesity. Besides medical, cultural and family reasons, important role in pathogenesis of adolescent obesity also play psychological factors. Psychological factors (stressful life events or changes, mental disorders, psychopharmacs) can be the same as in other periods of life but in adolescence they are specifically experienced because they interpolate into specifities of adolescent process. This is the reason why the problem of obesity should be seen in context of changes characteristic for adolescence. They can be understood and adequately treated in helping obese adolescents only through this context.
\end{abstract}

Key words: adolescence, obesity, psychological factors

Adolescencija je specifična i kompleksna razvojna faza tokom koje se dotadašnje dete preobražava u odraslu osobu, kako po telesnom izgledu, tako i psihosocijalnom funkcionisanju. Ma koliko je to prirodan i neminovan proces i ma koliko okolini delovao jednostavno, za svakog adolescenta i njegov psihički aparat je to vrlo komplikovan proces koji zahteva dosta napora i psihičkog rada na prihvatanju i psihološkoj elaboraciji preobražaja kako bi se oni integrisali u novu sliku, predstavu i funkcionisanje svakog adolescenta. Telesne promene koje donosi pubertet nisu samo kamen temeljac i svih ostalih promena već istovremeno i značajan izvor dilema i problema adolescenata.

Među problemima koji su izvor ili posledica adolescentnih transformacija jeste i gojaznost. Gojaznost koja započinje u adolescentnom uzrastu, istina, nije tako česta, ali je vrlo specifičan i gotovo uvek multifaktorijelno uzrokovan problem. Ona može biti posledica sadejstva ili predominacije genetskih, bioloških - somatskih, medicinskih, kulturoloških, ponašajnih, porodičnih i psiholoških faktora.

Ako je jedan roditelj gojazan dete i adolescent imaju 50\% šanse da budu gojazni, a ako su gojazna oba roditelja procenat šanse se povećava na $80 \%$ (1). U kojoj meri je to genetska predispozicija, a u kojoj je to rezultat poistovećivanja sa roditeljima $\mathrm{i}$ njihovim odnosom prema hrani i telu, teško je reći. U svakom slučaju, kulturološki i porodični odnosi prema hrani i izgledu su nesumnjivo značajni i utiču ili uzrokuju gojaznost dece i adolescenata.

Gojaznost adolescenata je uglavnom nastavak gojaznosti dece, ali i sama adolescencija i specifični psihološki faktori adolescencije mogu doprineti ili izazvati gojaznost baš u adolescenciji. Gojaznost koja počinje u adolescenciji češće počinje na početku adolescencije, kada su telesne promene intenzivnije, a psihološke burnije, nego u daljim fazama adolescencije. Osim psiholoških problema specifičnih za adolescenciju, među dodatnim psiholoških faktorima su svakako stresni životni događaji i promene, kao što su separacije, razvodi, preseljenja, smrt, zlostavljanje, porodični i vršnjački problemi, nisko samopoštovanje. Ovi događaji se dešavaju i u drugim fazama života, ali u adolescenciji imaju specifično značenje. Takođe i neki 
psihofarmaci i poremećaji mentalnog zdravlja, a pre svega depresivnost, anksioznost, fobije i opsesivno-kompulzivni poremećaji, mogu biti razlozi za nastajanje gojaznosti.

Adolescenti koji imaju psihološke probleme jedu više, ne zbog osećaja gladi, već da bi jedenjem i hranom izazvali zadovoljstvo ili umirenje. To je vrlo često manevar protiv nezadovoljstva, napetosti i frustracija izazvanih nekim psihološkim problemima i konfliktima (2).

Što se tiče psihosocijalnih faktora, u celini, H. Bruh (H. Bruch) (3) ih deli na one koji: a) uzrokuju gojaznost; b) koji su posledica gojaznosti i c) one koji su izazvani željom adolescenata da oslabe.

Adolescenti se goje najčešće na dva načina: stalnim grickanjem hrane ili povremenim prejedanjem. Ni jedan ni drugi akt nisu podsticani osećajem gladi već češće osećajem dosade, nezadovoljstva i neaktivnošću ili, suprotno, napetošću i strahovima. H. Bruh je utvrdila suprotnosti između ponašanja gojaznih i anoreksičnih adolescenata. Gojazni se „prejedaju-goje-postaju neaktivni“, za razliku od anoreksičnih koji „ne jedu-mršave-postaju hiperaktivni“. Važno je napomenuti da hiperaktivnost anoreksičnih, makar i sportska, nije nastala željom za kondicijom i dobrim telesnim stanjem već potrebom da se istroši svaka prekomerno ili neoprezno uzeta kalorija.

U povoljnom razvoju, adolescenti razviju doživljaj sopstvene telesne autonomije, prepoznavanja sopstvenih telesnih signala i potreba, osećaju odgovornost prema njima i nauče da njima vladaju, da ih drže pod kontrolom. Za razliku od njih, gojazni adolescenti nemaju osećaj sopstvene autonomije niti autonomije sopstvenog tela, nemaju kapacitete da prepoznaju njegove potrebe i da na njih adekvatno, sa merom i kontrolom, odgovore, nemaju osećaj sopstvene odgovornosti prema telu i izgledu. Kao da je njihovo telo i dalje pod roditeljskom kontrolom i odgovornošću.

Gojaznost može biti vezana i za specifičan odnos ovih adolescenata prema seksualnosti - umesto seksualnog zadovoljstva pribegavaju regresivnom i supstitutivnom, oralnom zadovoljstvu. Ovo su adolescenti koji su, kao deca, na svaki signal, bili umirivani i zadovoljavani hranom od strane njihovih majki. Tako su hrana i jedenje postali način za umirenje, neutralizaciju nezadovoljstava i frustracija i dostizanje zadovoljstva i blagostanja.

Adolescenti su često depresivni, što je praćeno osećanjem dosade, praznine i beskorisnosti. Uzimanje hrane je za njih odbrambeni manevar kojim se brane od tih nepodnošljivih osećanja, ali i način da se osećaju bolje. Nekima od njih, ogromno telo daje osećaj sigurnosti i zaštićenosti.

Gojaznost je, takođe, za neke adolescente, zaštitnik od spoljašnje sredine, garant integriteta i vrednosti slike o sebi. U tom smislu, gojaznost bi se mogla svrstati u korpus psihosomatskih reakcija i poremećaja (4).

Da bi se bolje razumeo psihološki odnos gojaznosti i adolescencije moraju se poznavati, makar osnovna, dešavanja u psihičkom svetu adolescenata. 


\section{Specifičnosti psihosocijalnog razvoja i telesnih promena u adolescenciji}

Telo, koje se rascveta pubertetom, izaziva kod najvećeg broja adolescenata radost, ponos, divljenje i osećaj moći. Svaki santimetar visine, obima mišića, struka ili grudi izaziva istinsku fascinaciju i neopisivo uzbuđenje, zadojeno uvek novim iskustvom snage i sile nagona, pre svega seksualnog. Telo adolescenta postaje istinski Corpus eroticus, a svaki pokret, pogled, misao, reč, pramen kose ili deo garderobe su u funkciji libida. Istovremeno, snaga tela i probuđene agresivnosti, teškoća i neiskustvo u njenoj kontroli doprinose uobičajenoj neobuzdanosti i neumerenosti adolescenta, kojoj se adolescenti takođe raduju, za razliku od njihove okoline. Konačno, telo se svojom veličinom i oblikom vrlo približava telu odraslih što adolescentu stvara doživljaj ili iluziju dostizanja željene zrelosti i statusa odraslih. Zbog svega toga bi se moglo pomisliti da je telo neprestani izvor zadovoljstva, nova uzbudljiva realnost $u$ kojoj adolescenti isključivo uživaju i kojoj se bezgranično raduju.

Međutim, postoji i druga, manje bajkovita strana medalje, jer je odnos adolescenta prema sopstvenom telu naravno mnogo kompleksniji, hirovitiji i ambivalentniji. Prihvatanje i elaboracija telesnih preobražaja i intenziviranih nagona je dug i komplikovan proces, na svesnom i nesvesnom planu, koji zahteva mobilizaciju celokupnih psiholoških potencijala adolescenta (5). Telo se menja pod uticajem impulsa iz mozga $i$ to nema nikakve veze sa psihičkim aparatom, sa njegovim očekivanjima, njegovom eventualnom spremnošću na promene ili željom za njima. Psihički aparat tako ne učestvuje $u$ inicijaciji telesnih promena, on ih jednostavno i u najboljem slučaju prati i njima se prilagođava. Kako se, s druge strane, sve ove promene dešavaju dosta brzo, tokom 2-3-4 godine, nema suviše vremena za prilagođavanje. Telesne promene se mogu zbog toga privremeno doživeti kao strane, neželjene, pritiskajuće što nosi rizik od rascepa između some i psihe, pa zahteva od adolescenta dodatan i nemali napor za integraciju u psihički aparat predstave o tom novom telu kao novom objektu - novom pre svega po obličju i po funkcionalnoj seksualnosti.

Privikavanje i prilagođavanje na novo telo razlozi su za sklonost adolescenata da sate provode ispred ogledala ili u kupatilima - da se ogledaju, razgledaju, upoznaju, razmišljaju o svom telu, da mu se dive ili da zbog njega budu nesrećni. Najveći broj adolescenata vrlo rado i lako eksperimentiše sa svojim telom: menjaju izgled, frizure, šminku, stavljaju minđuše i tetovaže, ističu ono što smatraju lepim, dobrim ili ono što su već prihvatili, a pokrivaju ili prikrivaju nedostatke ili one delove kojima nisu zadovoljni ili na koje se nisu privikli. Tako telo postaje poligon za eksperimentisanje, ali i poligon za izražavanje unutrašnjeg sveta - ono što adolescent misli, doživljava i oseća često može ili mora da se vidi spolja, pa je igra telom često rečitija od verbalnih poruka.

U nekim slučajevima i nekom vremenu, za neke adolescente, telo se može pretvoriti u objekt u koji se gotovo isključivo narcistički investira, najčešće kroz razne dijete, vežbe oblikovanja tela, bildovanje. I što su narcistička ranjivost, osetljivost i 
frustriranost veće, a nesigurnost izraženija, to su želja i strast ka investiranju u telo, ka njegovom vajanju, preoblikovanju ili prekrajanju veći. Kao da zadovoljstvo telom treba da, kroz estetsku gratifikaciju, nadoknadi nepostojeći osećaj zadovoljstva sobom kao celovitim bićem, nedostatak osećaja dostignutosti stabilnog i definitivnog identiteta.

Telo je takođe nosilac i nagona koji izmiču kontroli i kojima adolescenti tek uče da vladaju i da ih kontrolišu. Nagone koji preplavljuju neki adolescenti pokušavaju da kanališu okrećući ih, odbrambeno, put intelektualizacije. Beskrajno filozofiranje, čitanje, besomučno slušanje muzike, krstarenje internetom, bavljenje politikom može zato biti sofisticirani odbrambeni manevar od nagona, pre svega seksualnog. Sličan manevar je asketizam, najčešće u formi vegetarijanstva, čistunstva, moralnosti, odanosti religiji i sektama, kojim adolescenti pokušavaju da potpuno uguše i ponište nagone s kojim ne mogu drugačije da izađu na kraj. Možda najdrastičniji primer odbacivanja seksualnog nagona i seksualnog tela nude anoreksične i neke bulimične pacijentkinje koje mršavljenjem uništavaju svaki atribut ženskosti i svaki znak seksualnosti, sa idejom da telo pretvore u samo fizički, minimalno neophodni, podržavalac intelektualnog perfekcionizma.

Zbog svega toga može se reći da telo postaje ne samo inicijator dilema, teskobe i teškoća adolescenta već i mesto, reprezent i sedište njegovih unutrašnjih dilema i konflikata. Ukupan odnos adolescenta prema sopstvenom telu rezultat je zapravo kako podsticaja tela, tako i prilagođavanja i odbrambenih manevara psihe (6). Telu se divi, telo hrani narcizam, podržava i snaži Ja adolescenta, ali mu istovremeno stvara i probleme. Kada su ovi problemi veći onda su nemarnost, nipodaštavanje, negiranje ili simboličko odbacivanje delova sopstvenog tela ili tela u celini ponekad neophodni, ali prolazni odbrambeni manevar, uslovljen nemogućnošću da se prihvate neminovne transformacije, a pre svega zrela, genitalna seksualnost. Seksualno telo, koje postaje reproduktivno funkcionalno, možda je najveći problem adolescencije, bez obzira na to što mu se adolescenti toliko raduju. Dobar broj adolescenata se oseća nekomforno, nesigurno, nekompetentno i nevešto u svom seksualno zrelom telu.

Adolescentno telo tako može predstavljati izvor neizmernog nezadovoljstva, sumnji, osećaja neadekvatnosti i psihološkog trpljenja, koje se, između ostalog, može smanjiti ili umiriti preteranim unosom hrane i posledičnom gojaznošću.

Osim telesnih promena i prihvatanja svog novog tela, adolescencija podrazumeva i druge, psihosocijalne promene: promene odnosa prema roditeljima i psihološko odvajanje od njih, kao i promena odnosa prema autoritetima i drugim odraslim, na putu sazrevanja i osamostaljenja; promena odnosa sa vršnjacima i traženje svog mesta i uloge među njima; promena odnosa i povećanje odgovornosti prema sopstvenom životu i ponašanju, zdravlju i bolesti.

Svi pomenuti procesi neophodnih promena i preobražaja remete celokupnu psihičku strukturu adolescenata, što se iskazuje kroz promenljivost njihovih psihičkih stanja, raspoloženja, osećanja i ponašanja i stalno smenjivanje regresivnih i 
progresivnih nivoa psihosocijalnog funkcionisanja. Zato, sve veći broj adolescenata ima zaista burnu i problematičnu adolescenciju koja generiše izvesne lakše ili teže, kratkotrajnije ili dugotrajnije psihopatološke fenomene, simptome, sindrome i poremećaje. Njihova ozbiljnost i trajanje su produkt, kako intenzivnosti intrapsihičkih dešavanja u svakom adolescentu i snage njihove ličnosti da sa svim tim burama na dobar način izađe na kraj, tako i ponašanja i odnosa okoline, a pre svega porodice i škole, prema adolescentu.

Nezadovoljstvo, napetost, strahovi i depresivnost su najčešći psihopatološki fenomeni koji prate adolescenciju. Jedan od načina da se sa njima adolescenti nose je i specifičan odnos prema hrani. Neki od njih gojaznošću maskiraju svoju nepripremljenost za seksualnu ulogu i funkcionisanje, neki hranom umiruju nezadovoljstvo sobom i svojim životom ili postignućima, napetost i depresivnu bezvoljnost, osećaj praznine i neaktivnost.

\section{Odnos gojaznih adolescenata prema telu i hrani}

Osim svih medicinskih razloga i socio-kulturnih faktora za prekomernu telesnu težinu i gojaznost, postoji i značajan doprinos psiholoških elemenata u nastajanju i održavanju ovog poremećaja (7).

Među psihološkim faktorima značajni su odnos prema hrani i mogućnost samokontrole. Adolescenti sa prekomernom težinom imaju teškoću da neke situacije, odnose i osećanja kanališu ili prorade na adekvatan način, kroz psihički aparat, zbog čega osećaju napetost, nervozu, uznemirenost, tugu ili bes. Većinu ovih osećanja, kada su intenzivna ili preplavljujuća, ovi adolescenti „rešavaju” uzimanjem hrane. Osim medicinskih razloga za ovaj tip reagovanja, značajnu ulogu igraju i oralne fiksacije (psihološko zadovoljenje kroz usta) koje su dominantne kod ovih osoba, a koje su, kao što je već rečeno, naučene od strane majki ili njihovih zamena koje su o deci brinule. Kod njih, uzimanje hrane predstavlja prvu reakciju na frustracije, jer izaziva trenutno rasterećenje i umirenje i jer predstavlja uobičajen ili naučen način za obezbeđenje psihičkog mira. Slabost kontrole održava ovu tendenciju pa adolescenti jedu dok ne dostignu osećaj spokojstva.

Osim toga, odnos gojaznih adolescenata prema uzimanju hrane ima gotovo adiktivan karakter - hrana se uzima u svakoj uznemiravajućoj situaciji (bilo pozitivnoj ili negativnoj), što izaziva osećanje krivice jer vodi novom uvećanju težine. Kako su osećanja nezadovoljstva ili krivice nepodnošljivi, sledi novo uzimanje hrane da bi se umirili. Ovaj krug grešaka kao posledicu, na duže staze, ima povećanje telesne težine ili njeno održavanje.

Tako stečeno trajnije uvećanje telesne težine i gojaznost izazivaju dodatne probleme. Iako su svi adolescenti vrlo osetljivi na svoj izgled, pogotovu u početku adolescencije i fazi psihološkog privikavanja na telesne preobražaje, gojazni adolescenti 
imaju još veću osetljivost i veći stepen nezadovoljstva, niskog samopoštovanja i drugih oblika psihološkog trpljenja. Nisko samopoštovanje izaziva novo i sve veće nezadovoljstvo, ovo pak napetost koje se opet redukuje uzimanjem novih količina hrane.

Stid i krivica zbog različitosti od drugih, pre svega vršnjaka, najčešća su i najbolnija osećanja. Nekada čak i gađenje prema sopstvenom telu nije retko.

Osećaj sopstvene neadekvatnosti (zbog izgleda i nemogućnosti kontrole uzimanja hrane) čest je doživljaj koji dodatno urušava samopouzdanje i samopoštovanje ovih adolescenata, sve do konačnog osećaja inferiornosti. Kako su ova osećanja adolescentima takođe nepodnošljiva umirenje se kod gojaznih adolescenata „rešava“ novim uzimanjem hrane - i tu se krug problema i grešaka zatvara. Osećaj tuge ili depresivnosti, sa pratećim osećanjem neraspoloženja i bezvoljnosti, takođe su česti u ovoj grupi adolescenata i takođe se ,rešavaju“ uzimanjem hrane.

Zbog toga je problem gojaznosti ne samo medicinski problem, sa svim telesnim rizicima, već i značajan psihološki problem - kako po poreklu, tako i po posledicama. Psihološke posledice su nisko samopoštovanje, problemi u odnosima sa vršnjacima, remećenje normalnog psihosocijalnog razvoja, ali i moguć razvoj raznih psihopatoloških fenomena i poremećaja: anksioznost, razne fobije, psihosomatski poremećaji, depresivnost, zloupotreba duvana, alkohola i psihoaktivnih supstanci. Posebno je značajno da među gojaznim adolescentkinjama ima, po nekim istraživanjima, i do 20-30\% bolumičnih devojaka što predstavlja poseban problem u lečenju.

Psihološki elementi u problemu gojaznosti i psihološke posledice gojaznosti nameću neminovnost da se u proces lečenja uključe i kontinuirano obezbede i psihološka pomoć i podrška.

\section{Literatura}

Hebebrand J, Martin A., Child and Adolescent Obesity: Causes, Consequences, Prevention and Menagement. J.Am.Acad.Child Adolesc.Psychiatry, 2004;4:505-506.

Butor P. M., Some Psychological Viewpoints on Obesity. In:, Kiess W, Marcus C, Wabitsch M., Obesity in Childhood and Adolescence., Karger 2004; 9: 124-136.

Bruch H., Obesity in Adolescence. In: Caplan S, Lebovici S., Adolescence Psychological Perspectives. Basic Books Inc., New York, 1969.

Marcelli D, Braconnier A., Adolescence et psychopathologie, Masson, Paris; 2008: 124-136.

V. Ćurčić, Psihološko značenje tela u adolescenciji. U: Krstić A., Jugoslovenska pedijatrijska škola - I deo,Udruženje pedijatara Jugoslavije, Herceg Novi, 2002: 97-103.

V. Ćurčić, Govor tela u adolescenciji. U. B. Ćorić, Ljudi govore - psihijatrija između tela $i$ duše, Mrlješ Beograd, 2002, 119-129.

V. Ćurčić, Program psihološke obrade i tretmana. U: Banićević M., Medicinski pravilnik Centra za prevenciju i lečenje gojaznosti kod dece i adolescenata, Čigota, Zlatibor, 2008: 20-26. 